\title{
Optimization Method for Grid Purchasing Electricity Under the Constraints of Low-Carbon
}

\author{
LIU Dun-nan ${ }^{1}$, YING Yu-hang ${ }^{1, \star}$ and WANG Hai-chao ${ }^{2}$ \\ ${ }^{1}$ North China Electric Power University, Beijing 102206, P.R. China \\ 2Anhui Grid Power Trade Center, Anhui 230000, P.R. China
}

\begin{abstract}
World widely speaking, power industry plays an important player in the carbon emission and the carbon emission reduction field, and it is also the main part of the carbon trade market. Carbon constraint in electricity market will profoundly transform the original model of the power generation and electricity trade, and market behavior of every part in electric power market will be substantially changed. In this paper, the impact that carbon emission trade on electricity companies is mainly analyzed. First, optimum background for purchasing electricity of Shenzhen grid is analyzed. Next, optimization method for grid purchasing electricity is analyzed based on data of Shenzhen grid's purchasing electricity. It turns out that Optimization method can offer reliable strategies for grid enterprises purchasing electricity.
\end{abstract}

\section{INTRODUCTION}

With the development of carbon emission trade market in our country, in order to achieve the aim of carbon emission reduction, power industry has become the important part. In our country, total emission of electric carbon is great and the growth of that is fast. In 2010, amount of $\mathrm{CO}_{2}$ emission for electricity industry is nearly $50 \%$ of total amount. It proves that carbon emission reduction has high pressure and great potential in our country. Under the low-carbon economic model, traditional electricity industry is faced with tremendously transformed both in external condition and internal developing model.

Under the development of CDM (Clean Development Mechanism), based on carbon trade, grid company can regard energy conservation and environment protection benefit as economic benefit while purchasing electricity. That is to say, synthetically considering the energy conservation and pollutant emission reduction as economic benefit to decide the final optimization method for purchasing electricity.

In order to solve shortage about regardless of power generation external cost, this section suggests an optimization method with considering power generation external cost. Taking the energy conservation and pollutant emission reduction into account and considering production cost and external cost , at the same time, measuring integrated purchasing electricity cost and instructing grid company to make reasonable purchasing electricity priority. As a results, competence of clean energy grid connection can be improved.

\section{Optimization Background for Grid Purchasing Electricity}

The current electricity purchasing modes are considered mainly from the three principles (open, justice and fair) and economy. With the increasing emphasis from the whole society on energy-conservation and emission reduction, especially the emission reduction of carbon dioxide, which influences the global climate, is becoming the focus of international attention. Energy conservation, emission reduction and low carbon during electricity production have become the optimization objectives needing equivalent attention besides economic objective. Therefore, grid corporations should transfer the costs of energy conservation, emission reduction and low carbon into economic cost. It means that turning the statistical indices such as energy conservation and pollutant reduction into comparable and reference index and calculating comprehensive purchasing costs to determine purchase optimization scheme. The comparison between before-optimization and after- optimization is shown in Tab.1.

Table 1. Analysis on the influence of electricity purchase optimization on grid corporations and society.

\begin{tabular}{|l|l|l|}
\hline & Grid corporation & Society \\
\hline Economic & $\begin{array}{l}\text { The average } \\
\text { electricity } \\
\text { purchasing price } \\
\text { rises caused by } \\
\text { the change of the } \\
\text { electricity } \\
\text { purchase structure }\end{array}$ & $\begin{array}{l}\text { Wind power and } \\
\text { other clean energies } \\
\text { join the power grid. } \\
\text { Financial subsidies } \\
\text { increased. }\end{array}$ \\
\hline $\begin{array}{l}\text { Comprehe } \\
\text { nsive cost }\end{array}$ & $\begin{array}{l}\text { Rises } \\
\text { The proportion of } \\
\text { clean electricity } \\
\text { consumption is } \\
\text { increasing, producing } \\
\text { the benefits of energy } \\
\text { conservation and } \\
\text { emission reduction. }\end{array}$ \\
\hline
\end{tabular}




\section{Optimization Model of Grid Purchasing Electricity Under Constraints of Low Carbon}

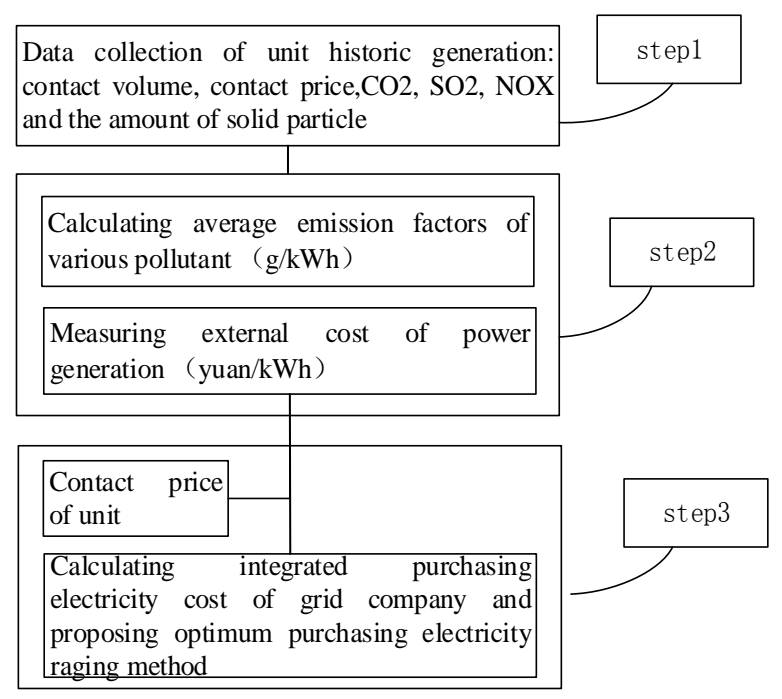

Figure 1. Optimization process of purchasing electricity under constraints of low carbon

\subsection{Data Collection}

Collecting amount of actual generation, contact volume, contact price, amount of $\mathrm{CO} 2$ emission, amount of SO2 emission, amount of NO2 emission, amount of solid particle emission and some other data from existing evaluating system of generating units, monitoring system of pollution emission, forecast system of electric load for a super short period and support system of grid trade.

\subsection{Calculation External Cost of Power Generation}

(1)Calculating emission factors of $\mathrm{CO}_{2}, \mathrm{SO}_{2}, \mathrm{NO}_{\mathrm{x}}$ and solid particle for each unit. The calculation formula is as follows.

$$
\begin{gathered}
e_{\mathrm{CO}_{2}, i}=\frac{M_{\mathrm{CO}_{2}, i}}{Q_{i}} \\
e_{\mathrm{SO}_{2}, i}=\frac{M_{\mathrm{SO}_{2}, i}}{Q_{i}} \\
e_{\mathrm{NO}_{X}, i}=\frac{M_{\mathrm{NO}_{X}, i}}{Q_{i}} \\
e_{P M, i}=\frac{M_{P M, i}}{Q_{i}}
\end{gathered}
$$

In which, $e_{\mathrm{CO}_{2}, i}$ is taken as $\mathrm{CO}_{2}$ emission factor of unit $i$. $e_{\mathrm{SO}_{2}, i}$ is taken as $\mathrm{SO}_{2}$ emission factor of unit $i . e_{\mathrm{NO}_{X}, i}$ is taken as $\mathrm{NO}_{2}$ emission factor of unit i. $e_{P M, i}$ is taken as solid particle emission factor of unit i. $M_{\mathrm{CO}_{2}, i}, M_{\mathrm{SO}_{2}, i}$, $M_{N O_{X}, i}$ and $M_{P M, i}$ are respectively taken as total emission amount of various pollutant of unit $i$.

(2)Synthetically considering of emission factors and unit governance cost of pollutant emission to forecast external cost of power generation. The calculation formula is as follows.

$$
C_{E C, i}=C_{C_{2}, i}+C_{S_{2}, i}+C_{N_{X}, i}+C_{P M, i}
$$

In which :

$$
\begin{aligned}
& C_{\mathrm{CO}_{2}, i}=f_{\mathrm{CO}_{2}} \times e_{\mathrm{CO}_{2}, i} \\
& C_{\mathrm{SO}_{2}, i}=f_{\mathrm{SO}_{2}} \times e_{\mathrm{SO}_{2}, i} \\
& C_{\mathrm{NO}_{X}, i}=f_{\mathrm{NO}_{X}} \times e_{\mathrm{NO}_{X}, i} \\
& C_{P M, i}=f_{P M} \times e_{P M, i}
\end{aligned}
$$

In which, $C_{E C, i}$ is taken as external cost of power generation for unit i. $C_{\mathrm{CO}_{2}, i}, C_{\mathrm{SO}_{2}, i}, C_{\mathrm{NO}_{x}, i}, C_{P M, i}$ are respectively taken as external cost of various pollutant. $f_{\mathrm{CO}_{2}}, f_{\mathrm{SO}_{2}}, f_{\mathrm{NO}_{\mathrm{X}}}, f_{\mathrm{PM}}$ are taken as governance cost of unit pollutant emission. Governance cost of unit pollutant emission is the cost should be paid for environment when each kind of pollutant is discharged. It is an artificial variable which can be corrected according to actual situation. 
Tab.2 Optimum analog data for company purchasing electricity.

\begin{tabular}{|c|c|c|c|c|c|c|c|}
\hline \multirow[b]{2}{*}{$\begin{array}{l}\text { Purchasing } \\
\text { Type }\end{array}$} & \multirow{2}{*}{$\begin{array}{l}\text { Installed } \\
\text { Capacity } \\
(M W)\end{array}$} & \multirow{2}{*}{$\begin{array}{l}\text { Contact } \\
\text { Price (Yuan } \\
\text { /MWh) }\end{array}$} & \multirow{2}{*}{$\begin{array}{l}\text { Generation } \\
\text { Amount(G } \\
\text { HW) }\end{array}$} & \multicolumn{4}{|c|}{ Amount of emission(ton) } \\
\hline & & & & $\begin{array}{l}\mathrm{CO}_{2} \\
\text { (1000-ton) }\end{array}$ & $\mathrm{SO}_{2}$ & $N O_{x}$ & $\begin{array}{l}\text { Solid } \\
\text { Particle }\end{array}$ \\
\hline $\begin{array}{ll}\text { Wind } & \text { power } \\
\text { plant } 1 & \\
\end{array}$ & 50 & 478 & 1.14 & 0 & 0 & 0 & 0 \\
\hline $\begin{array}{l}\text { Hydro-power } \\
\text { generating unit } \\
2\end{array}$ & 50 & 320 & 2.5 & 0 & 0 & 0 & 0 \\
\hline $\begin{array}{l}\text { Thermal power } \\
\text { generating unit } 3\end{array}$ & 900 & 478 & 52 & 406 & 3593 & 1624 & 431 \\
\hline $\begin{array}{l}\text { Thermal power } \\
\text { generating unit } 4\end{array}$ & 660 & 478 & 34 & 287 & 2530 & 1504 & 353 \\
\hline $\begin{array}{l}\text { Thermal power } \\
\text { generating unit } 5\end{array}$ & 600 & 478 & 28 & 239 & 2130 & 2552 & 277 \\
\hline $\begin{array}{l}\text { Thermal power } \\
\text { generating unit } 6\end{array}$ & 300 & 478 & 17 & 148 & 1328 & 1797 & 193 \\
\hline $\begin{array}{l}\text { Thermal power } \\
\text { generating unit } 7\end{array}$ & 250 & 466 & 12 & 112 & 2899 & 4380 & 381 \\
\hline
\end{tabular}

\section{Analysis on Example}

With the example, the proposed measuring in this page will be further illustrated. Simulation analysis is carried out for the partial purchasing electricity data of Shenzhen grid in 2014. Detailed optimization process is as follows.

\subsection{Collection of Historical Generation Data}

Optimum analog data for Shenzhen grid company purchasing electricity is shown in Tab.2.

In Tab.2, Wind power plant 1 has 33 wind generation units of $1.5 \mathrm{MW}$ installed capacity, and unit 7 is not installed desulphurization and denitrification device. Considering the impact of desulphurization and denitrification devices on contact volume.

\subsection{Calculating the External Cost of Power Generation}

(1)Calculating various emission factor pollutant for power generation, the result is shown in Tab.3.

Tab.3 Pollutant emission factors for power generations.

\begin{tabular}{|l|l|l|l|l|}
\hline $\begin{array}{l}\text { Object of } \\
\text { Purchasing } \\
\text { Electricity }\end{array}$ & $\begin{array}{l}e_{\mathrm{CO}_{2}, i} \\
(\mathbf{g} / \mathbf{k} \mathbf{W} \cdot \mathbf{h})\end{array}$ & $\begin{array}{l}e_{\mathrm{SO}_{2}, i} \\
(\mathbf{g} / \mathbf{k} \mathbf{W} \cdot \mathbf{h})\end{array}$ & $\begin{array}{l}\boldsymbol{e}_{\mathrm{NO}_{X}, i} \\
\mathbf{( g /} \\
\mathbf{k W} \cdot \mathbf{h})\end{array}$ & $\begin{array}{l}\boldsymbol{e}_{P M, i} \\
\mathbf{( g /} \\
\mathbf{k W} \cdot \mathbf{h})\end{array}$ \\
\hline $\begin{array}{l}\text { Wind } \\
\text { power plant } \\
1\end{array}$ & 0 & 0 & 0 & 0 \\
\hline $\begin{array}{l}\text { Hydro- } \\
\text { power } \\
\text { generating } \\
\text { unit 2 }\end{array}$ & 0 & 0 & 0 & 0 \\
\hline $\begin{array}{l}\text { Thermal } \\
\text { power } \\
\text { generating } \\
\text { unit 3 }\end{array}$ & 780.21 & 0.6899 & 0.3118 & 0.0828 \\
\hline $\begin{array}{l}\text { Thermal } \\
\text { power } \\
\text { generating }\end{array}$ & 833.34 & 0.7343 & 0.4366 & 0.1024 \\
\hline
\end{tabular}

\begin{tabular}{|l|l|l|l|l|}
\hline unit 4 & & & & \\
\hline $\begin{array}{l}\text { Thermal } \\
\text { power } \\
\text { generating } \\
\text { unit 5 }\end{array}$ & 841.03 & 0.7504 & 0.8989 & 0.0974 \\
\hline $\begin{array}{l}\text { Thermal } \\
\text { power } \\
\text { generating } \\
\text { unit 6 }\end{array}$ & 878.23 & 0.7874 & 1.0653 & 0.1157 \\
\hline $\begin{array}{l}\text { Thermal } \\
\text { power } \\
\text { generating } \\
\text { unit 7 }\end{array}$ & 892.31 & 2.3041 & 3.4816 & 0.3025 \\
\hline
\end{tabular}

(2)Calculating the external cost of power generation

According to the law for pollutant trade, governance cost of unit pollutant emission is shown as Tab.4.

Tab.4 Governance cost of unit pollutant emission.

\begin{tabular}{|l|l|l|l|l|}
\hline $\begin{array}{l}\text { Conversion } \\
\text { Coefficient }\end{array}$ & $\begin{array}{l}f_{\mathrm{CO}_{2}} \\
\text { (yuan } \\
\text { /ton) }\end{array}$ & $\begin{array}{l}f_{\mathrm{SO}_{2}} \\
\text { (yuan } \\
\text { /ton) }\end{array}$ & $\begin{array}{l}f_{\mathrm{NO}_{X}} \\
\text { (yuan } \\
\text { ton) }\end{array}$ & $\begin{array}{l}f_{P M} \\
\text { (yuan } \\
\text { /ton) }\end{array}$ \\
\hline Data & 80 & 3000 & 3000 & 1000 \\
\hline
\end{tabular}

Result of power generation external cost is shown in Tab.5. 
Tab.5 External cost of power generation.

\begin{tabular}{|l|l|l|l|l|l|}
\hline $\begin{array}{l}\text { Prchasin } \\
\text { g Type }\end{array}$ & $\begin{array}{l}C_{\mathrm{CO}_{2}, i} \\
\text { (yuan } \\
/ \mathbf{M W H} \\
\text { ) }\end{array}$ & $\begin{array}{l}C_{\mathrm{SO}_{2}, i} \\
\text { (yuan } \\
/ \mathbf{M W H} \\
\text { ) }\end{array}$ & $\begin{array}{l}C_{\mathrm{NO}_{X}, i} \\
\text { (yuan } \\
/ \mathbf{M W H} \\
\text { ) }\end{array}$ & $\begin{array}{l}C_{P M, i} \\
\text { (yuan } \\
/ \mathbf{M W H} \\
\text { ) }\end{array}$ & $\begin{array}{l}C_{E C, i} \\
\text { (yuan } \\
/ \mathbf{M W H} \\
\text { ) }\end{array}$ \\
\hline $\begin{array}{l}\text { Wind } \\
\text { power } \\
\text { plant 1 }\end{array}$ & 0 & 0 & 0 & 0 & 0 \\
\hline $\begin{array}{l}\text { Hydro- } \\
\text { power } \\
\text { generatin } \\
\text { g unit 2 }\end{array}$ & 0 & 0 & 0 & 0 & 0 \\
\hline $\begin{array}{l}\text { Thermal } \\
\text { power } \\
\text { generatin } \\
\text { g unit 3 }\end{array}$ & 62.42 & 2.07 & 0.94 & 0.08 & 65.50 \\
\hline $\begin{array}{l}\text { Thermal } \\
\text { power } \\
\text { generatin } \\
\text { g unit 4 }\end{array}$ & 66.67 & 2.20 & 1.31 & 0.10 & 70.28 \\
\hline $\begin{array}{l}\text { Thermal } \\
\text { power } \\
\text { generatin } \\
\text { g unit 5 }\end{array}$ & 67.28 & 2.25 & 2.70 & 0.10 & 72.33 \\
\hline $\begin{array}{l}\text { Thermal } \\
\text { power } \\
\text { generatin } \\
\text { g unit 6 }\end{array}$ & 70.26 & 2.36 & 3.20 & 0.12 & 75.93 \\
\hline $\begin{array}{l}\text { Thermal } \\
\text { power } \\
\text { generatin } \\
\text { g unit 7 }\end{array}$ & 71.39 & 6.91 & 10.44 & 0.30 & 89.04 \\
\hline
\end{tabular}

\subsection{Calculating and raging priority order for purchasing power}

Calculating and raging integrated purchasing electricity cost of the grid company as priority order for purchasing power. Integrated purchasing electricity cost and priority order is shown in Tab.6

Tab.6 Integrated purchasing electricity cost and priority order.

\begin{tabular}{|l|l|l|l|l|}
\hline $\begin{array}{l}\text { Object of } \\
\text { Purchasing } \\
\text { Electricity }\end{array}$ & $\begin{array}{l}C_{\text {pr,i }} \\
\text { (yuan } \\
\text { /MWh) }\end{array}$ & $\begin{array}{l}C_{E C, i} \\
\text { (yuan } \\
\text { /MWh) }\end{array}$ & $\begin{array}{l}\text { Ci } \\
\text { (yuan } \\
\text { /MWh) }\end{array}$ & $\begin{array}{l}\text { Cost } \\
\text { Rag } \\
\text { ing }\end{array}$ \\
\hline $\begin{array}{l}\text { Wind power } \\
\text { plant 1 }\end{array}$ & 478 & 0 & 478 & 2 \\
\hline $\begin{array}{l}\text { Hydro-power } \\
\text { generating unit } \\
\text { 2 }\end{array}$ & 320 & 0 & 320 & 1 \\
\hline $\begin{array}{l}\text { Thermal power } \\
\text { generating unit 3 }\end{array}$ & 478 & 65.50 & 543.50 & 3 \\
\hline $\begin{array}{l}\text { Thermal power } \\
\text { generating unit 4 }\end{array}$ & 478 & 70.28 & 548.28 & 4 \\
\hline $\begin{array}{l}\text { Thermal power } \\
\text { generating unit 5 }\end{array}$ & 478 & 72.33 & 550.33 & 5 \\
\hline $\begin{array}{l}\text { Thermal power } \\
\text { generating unit 6 }\end{array}$ & 478 & 75.93 & 553.93 & 6 \\
\hline $\begin{array}{l}\text { Thermal power } \\
\text { generating unit 7 }\end{array}$ & 466 & 89.04 & 555.04 & 7 \\
\hline
\end{tabular}

Tab.6 shows that the priority of purchasing hydropower and wind power has been improved with the consideration of electricity production external cost. The priority of purchasing thermal power has dropped because of the increasing of comprehensive cost caused by pollutant emission.

\section{Conclusion and Suggestions}

Under the background of carbon trading. the optimum plan for Shenzhen power grid purchasing electricity with the consideration of the electric power production externality has been proposed in this paper. The background of Shenzhen Power Grid purchasing electricity optimization has been analyzed and the external cost caused by electricity production has been totally cleared up. The electricity purchasing optimization model with the consideration of external cost of Shenzhen Power Grid Company has been established and the decision - making basis has been put forward, which will help to increase the generation capacity and realizing the energy conservation and emission reduction goal of our country.

\section{References}

[1] HE Jian-kun, ZHOU Jian ,LIU Bin. et al. Global Trends of Low Carbon Economy and China`s Responses [J].World Economics and Politics,2010,(4): : 18-35

[2] WANG Guan-qun, LIU Feng, MEI Sheng-wei, et al. Optimization Model and Algorithm for Contact Energy Decomposition [J]. Electric Machines and Control , 2012, 16(7):58-64

[3] QU Ru-xiao, WU Jie. Environmental Effect of Carbon Emission Permits Trade and Measurements[J]. Journal of Beijing Normal University(Social Sciences), 2009, 6:127-134.

[4] TIAN Kuo, ZENG Ming, SHI Lian-jun, et al. Free purchasing space and purchasing optimization strategies for provincial grid companies in market environment [J]. East China Electric Power,2009, 37(7):1090-1094

[5] ZHAO Yan, LIU Dun-nan, LI Lei, et al. An assessment method for power purchasing in East China Electric Power market [J]. Power System Automation,2008,32(3):26-29

[6] The national development and reform commission on climate change, "2011 China regional power grid baseline emission factor”, China clean development mechanism (CDM) network 